\title{
Digital Paradigm in Educational Management: The Case of Construction Education Based on Emerging Technologies
}

\author{
https://doi.org/10.3991/ijet.v15i13.14663 \\ Natalya Pugacheva $\left({ }^{\varpi}\right)$ \\ Kazan State University of Architecture and Engineering, Kazan, Russia \\ pugachevana@rambler.ru , natalya-pugacheva@yandex.ru \\ Tatyana Kirillova \\ Research Institute of the Federal Penitentiary Service of Russia, Moscow, Russia \\ Olga Kirillova \\ Chuvash State University named after Ulyanov, Cheboksary, Russia \\ Anastasia Luchinina \\ Vyatka State University, Kirov, Russia \\ Irina Korolyuk \\ College of State and Municipal Service, Izhevsk, Russia \\ Aleksandr Lunev \\ Kazan National Research Technical University named after Tupolev-KAI, \\ Kazan, Russia
}

\begin{abstract}
The effective use of emerging technologies demands the training of highly qualified personnel with digital literacy professional skills. The aim of the study is to characterize the virtual construction site as a digital resource for pedagogical management of the educational process in the construction university. The principles of tradition and innovation have become the methodological basis for linking best practices in pedagogical management of the learning process with qualitative changes based on modern digital technologies. A virtual construction site entails a digital resource imitating professional activities and providing integration of science, technology, pedagogical management of educational process on the basis of common standards of data description. The content of the virtual construction site represents a complex multi-level menu corresponding to the construction stages. Efficiency criteria (metaproject, activity, digital, relevant, complex) allow to find out the level of formation of ability to work with digital technologies. The principles of selection and structuring of content ensure its validity and updating. The practical significance of the research is provided by the didactic functions of the virtual construction site, providing for the involvement of students in design and construction activities, establishment of interdisciplinary relations. The social significance consists in personalisation of the educational process and formation of the students' professional individuality.
\end{abstract}


The originality of the study lies in the justification of the digital paradigm of higher education, which forms a pedagogical community that promotes and actively integrates digital content into the educational process.

Keywords_-Digital education paradigm; educational management; emerging technologies; virtual construction site.

\section{Introduction}

The relevance of the stems from the spread of digital learning tools to personalise the learning process and develop 21 st century skills $[1,2]$, as well as to ensure the openness of educational resources and continuity of lifelong learning [3].

Pedagogical management of the educational process ivolves sustainable interaction of subjects of teaching and learning in order to obtain new qualitative results in the development of educational content. The main functions of pedagogical management are to: optimise the learning process through comprehensive task planning; select and structure learning materials as a tool for learning and cognitive activities [4]; ensure the economical and expedient use of time, conditions, resources, as well as the rapid correction of forms, methods, means of learning [5]. The algorithm of pedagogical management of the educational process in the university can include several basic steps:

1. Identifying peculiarities of the educational process and setting of tasks. The first step provides for procedural and systematic pedagogical management, which ensures the inaccuracy of teaching and learning, i.e. not just the addition of activities, but the achievement of overall results [6].

2. Establishing criteria for mastering the content of educational programmes. The second step ensures that teacher management is focused and continuous, and that teaching and learning actors interact in a sustainable manner to produce new quality learning outcomes [7].

3. Defining the principles of selection of educational material. The third step focuses on the integrative integrity and accessibility of learning materials, as well as on the openness of pedagogical management to ensure the intensity of information exchange with the environment to effectively address the challenges [8].

4. Defining the principles of structuring training material. The fourth step focuses on the dynamism, nonlinearity of the educational process and exponential growth of the quality and variants of interaction of subjects of teaching and learning, as well as the innovative orientation of pedagogical management, ensuring the introduction of new forms, methods and means of education [9].

5. Organisation of the educational process. The fifth step leads to a dialectical relationship between the objectives of the learning process, the criteria for mastering the content of educational programmes, and the operational correction of forms, methods, techniques and tools as an imperative for reliable pedagogical management [10].

Paradigms, as recognised scientific achievements, have for some time provided the scientific community with a model of problem-solving and problem-solving. The 
spread of emerging technologies has led to the formation of new paradigms for the organisation of higher education. The digital paradigm is just beginning to take shape. However, it is already possible to identify several stages in its development: 1) creation of digital technologies to prepare students for successful personal/professional activities; 2) introduction of digital textbooks, M-learning for the development of skills of the 21st century [11];3) development of digital educational resources for the training of specialists in modern digital technologies [12]. The digital paradigm is being shaped and developed as a component of the digital economy [13]. The labour market requires highly qualified personnel with certain competences for the development and implementation of emerging technologies [14].

This highlights specific aspects of the development of digital pedagogical management tools:

1. The creation of educational programmes capable of ensuring digital literacy for future professionals [15]

2. The development of cloud-based education systems and open educational resources based on digital content [16]

3. The adaptation of virtual reality technologies to the learning process [17]

4. The introduction of electronic portfolios and personal electronic classrooms.

The objects of this study are digital resources of pedagogical management of the educational process at the university. Moreover, the purpose of the study is to characterise the virtual construction site of a multi-storey residential building as a digital resource for pedagogical management of the educational process in a construction university.

\section{Materials and Methods}

\subsection{Research design}

The methodological basis for the study was the principles of tradition and innovation. The principle of tradition provides for the use of best practices and ensures the existence of a constant in the pedagogical management of the educational process, on the basis of which a new one is formed. Updating tradition means the desire to understand and express the old in a new way. It is tradition that ensures a sustainable relationship between education, social development, science and technology. Tradition and experience are dialectically interrelated. On the one hand, traditions reflect best practices. On the other hand, traditions are a source of innovation, provide continuity in the cultural and civilisational development of society and a tolerant attitude of new generations to the values of the past.

Table 1 shows the relationship between functions, algorithm and educational management tools. 
Table 1. Functions, algorithm and tools of educational management

\begin{tabular}{|l|l|l|}
\hline \multicolumn{1}{|c|}{$\begin{array}{c}\text { Functions } \\
\text { pedagogical management }\end{array}$} & \multicolumn{1}{c|}{$\begin{array}{c}\text { Algorithm } \\
\text { pedagogical management }\end{array}$} & \multicolumn{1}{c|}{$\begin{array}{c}\text { Tools } \\
\text { pedagogical management }\end{array}$} \\
\hline $\begin{array}{l}\text { Optimisation of the educational } \\
\text { process through integrated } \\
\text { planning of tasks }\end{array}$ & $\begin{array}{l}\text { Identification of peculiarities of the } \\
\text { educational process and setting of } \\
\text { tasks; establishment of criteria for } \\
\text { mastering the content of educa- } \\
\text { tional programs }\end{array}$ & $\begin{array}{l}\text { Creation of educational programs and } \\
\text { creation of personalised learning paths } \\
\text { that can ensure digital literacy of fu- } \\
\text { ture specialists }\end{array}$ \\
\hline $\begin{array}{l}\text { Selection and structuring of } \\
\text { training material as a tool for } \\
\text { learning and cognitive activi- } \\
\text { ties }\end{array}$ & $\begin{array}{l}\text { Defining the principles of selection } \\
\text { and structuring of training material. }\end{array}$ & $\begin{array}{l}\text { Introduction of electronic textbooks, } \\
\text { electronic libraries; creation of train- } \\
\text { tional systems; development of open }\end{array}$ \\
\hline $\begin{array}{l}\text { Ensuring that time, conditions } \\
\text { and resources are spent eco- } \\
\text { educational resources } \\
\text { that the forms, methods and } \\
\text { means of training are promptly } \\
\text { corrected }\end{array}$ & Educational organisation & $\begin{array}{l}\text { Organisation of open online courses; } \\
\text { development of digital resources and } \\
\text { adaptation of virtual reality technolo- } \\
\text { gies to the educational process; intro- } \\
\text { duction of electronic portfolios and } \\
\text { personal electronic classrooms }\end{array}$ \\
\hline
\end{tabular}

Table 1 shows that the interrelation of functions, algorithms and pedagogical management tools provides a synergetic effect in the learning process. The digital paradigm of higher education forms a pedagogical community that promotes and actively introduces into the educational process digital content adapted to modern formats and requirements, associated with information databases and search engines of a narrow professional profile, including virtual reality technologies.

The principle of innovation provides for the organisation of pedagogical management on the basis of constant, expedient, evolutionary changes based on modern achievements of science, technology, and human resources management technologies [18]. The principle of innovation ensures the existence of variability in pedagogical management, on the basis of which new methods, tools, and digital resources are introduced into the educational process.

The development of the digital economy has highlighted the importance of the principles of tradition and innovation. The dialectical relationship between the principles of tradition and innovation reflects the state of science and technology, serves as a basis for fundamental research, and justifies the feasibility of applied research [19]. The digital paradigm develops on the basis of the synthesis of scientific traditions and digital technologies of the new generation. Justification of the effectiveness of pedagogical management on the basis of the digital paradigm allows establishing the interrelation of traditions and innovations in the educational process of the university.

In conducting this study, a complex of theoretical and empirical methods is applied, adequate to the set objective. Theoretical methods included are the study, analysis and synthesis of national and international experience of pedagogical management of the educational process in the university on the basis of the digital paradigm of education. Empirical methods include: observation, conversations, online survey, and a forum. Experimental work to test the effectiveness of the virtual construction site was carried out in three stages: stating, forming, and control. 


\subsection{Sample}

The experimental work was attended by 500 people: 50 teachers, 450 students of the University of Architecture and Civil Engineering. Convenient samples of teachers and students were drawn up. The sample of teachers included professors (average age 51 years) and associate professors (average age 36 years), who conduct training in the discipline "Life safety" with students studying in the direction of training "Industrial and civil engineering". The sample of students included students of 3-4 courses, studying in the direction of training "Industrial and civil engineering". None of the teachers, nor students, refused to participate in the experimental work.

\subsection{Survey}

At the stating stage with the help of online survey the attitude of teachers and students to digital resources was learned, after which the criteria of efficiency of implementation of virtual construction site in the educational process were determined. The questionnaire includes two closed-ended questions with a choice of one answer option; four closed-ended questions accompanied by video/audio material with a choice of several answer options; four closed-ended questions with a choice of several answer options; and support for the respondent's e-mail question. A special constructor was used to compile online survey questions [20]. An invitation to the survey was sent out via Email or Telegram (cross-platform cloud messenger). The questionnaire was posted in a special section on the website of the university, as well as sent to respondents through Telegram. Of the respondents invited to the survey, $74 \%$ filled out a questionnaire on the first day at a convenient time and place. The online survey made it possible to track the results in real time and to send the results to respondents for review. In the course of the survey, the entered values were automatically checked, and the mandatory filling of questions was controlled. Repetition was protected by the identification of respondents by IP and by an individual account (Cookie). The database with respondents' answers was converted into files suitable for processing by the SPSS and Statistica applications. The results of the survey were discussed in 5 online focus groups in the forum. Each focus group included 19 people: 10 teachers and 9 students. Focus groups included teachers and students who were not personally familiar with each other. Students were appointed as focus group moderators. The forum was held for one hour over the course of one day. The blogs of the participants became a part of the forum. They wrote down their ideas and recorded events related to the research topic. At the formative stage, the educational material (content) was selected and structured, and a virtual construction site for a multi-storey residential building was created. At the control stage the levels of mastering the training material on organisation and management of the construction of a multi-storey residential building were revealed.

\section{$2.4 \quad$ Research limitations}

Research limitations include a convenient sample of respondents. 


\section{Results and Discussions}

The basic results of research consist in definition of essence and the maintenance of a virtual building site of a multi-storey apartment house; finding out of criteria of efficiency of introduction of a virtual building site in educational process; definition of principles of selection and structuring of a content of a virtual building site; experimental work on check of efficiency of a virtual building site.

\subsection{Essence and content of the virtual construction site of a multi-storey residential building}

The essence of the virtual construction site is that it is a digital resource of pedagogical management of the educational process for the development of professional skills of the 21 st century and automated assessment of different levels of complexity. $3 \mathrm{ds}$ Max and Autodesk Revit software was used to create the virtual construction site [21]. The main characteristics of the virtual construction site are: cross-platformity; multimedia interactive content imitating professional activities; integration of science, technology; and pedagogical management of the educational process on the basis of common standards of data description (Fig 1,2).

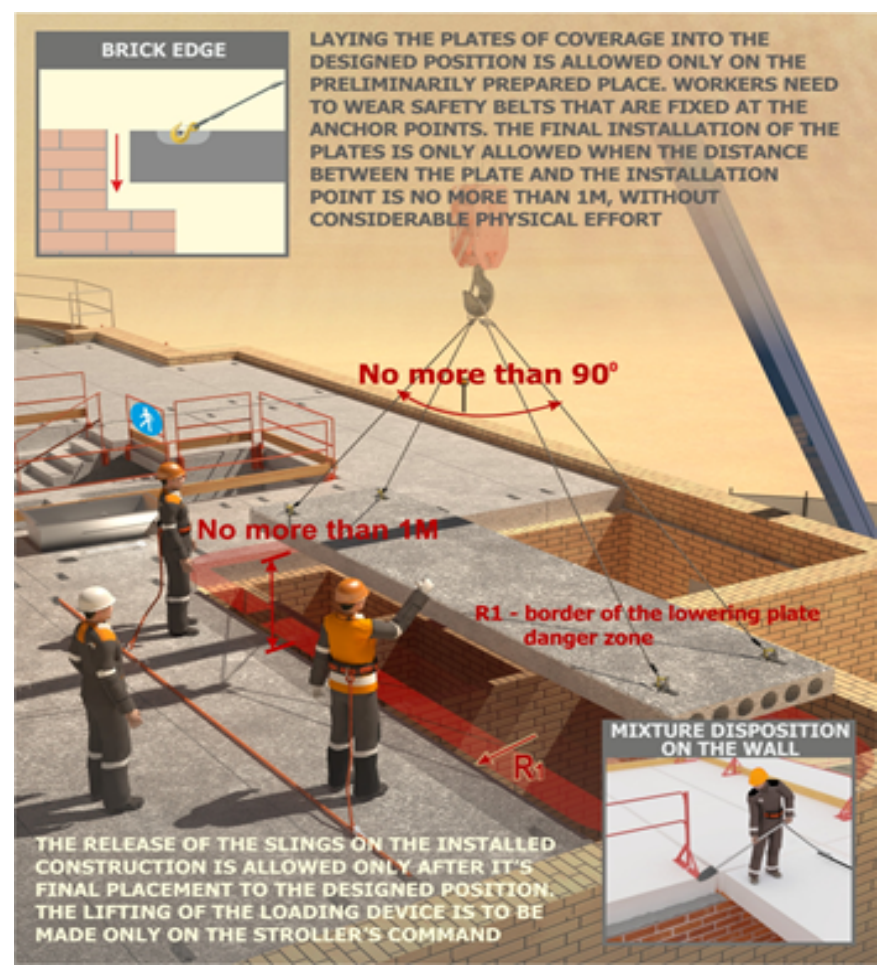

Fig. 1. Laying the floor slabs 


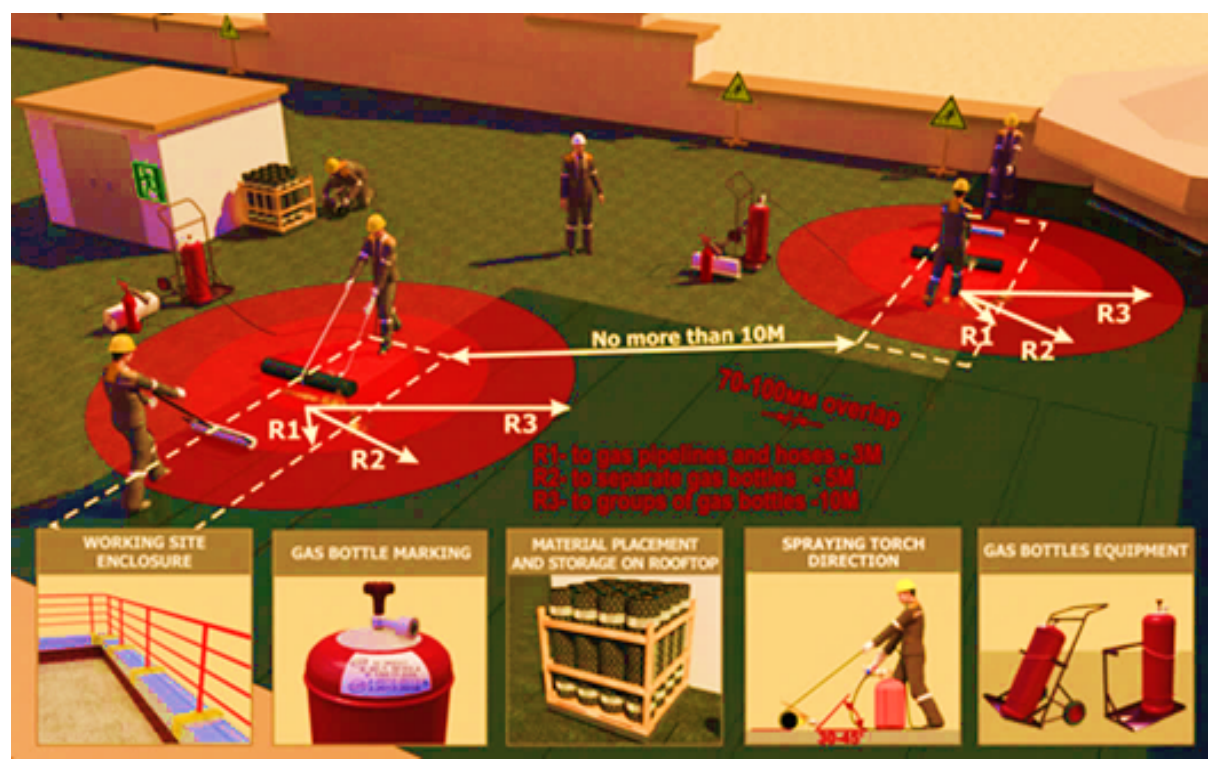

Fig. 2. Ensuring occupational safety when performing roofing work

Figs 1 and 2 show that the virtual construction site includes an interactive 3D model of a multi-storey residential building at different stages of construction with animation of construction processes, additional text, graphic information, video and interactive presentations. By managing three-dimensional models of construction processes, students have the opportunity to observe the construction process step by step.

The content of the virtual construction site is a complex multi-level menu with a permanent vertical line, each element of which has a drop-down menu. The points of the permanent vertical line correspond to the construction stages: preparatory, underground, above-ground, and finishing. Each element of the constant vertical line has a drop-down menu (Table 2).

Table 2. Maintenance of the virtual construction site

\begin{tabular}{|l|l|}
\hline Elements of a constant vertical line & \multicolumn{1}{c|}{ Drop-down menu } \\
\hline Preparatory phase & $\begin{array}{l}\text { Construction documentation, off-site preparation works, on-site prep- } \\
\text { aration works, industrial safety and labour protection, operational } \\
\text { dispatch control }\end{array}$ \\
\hline Underground stage & $\begin{array}{l}\text { Construction documentation, excavation works, foundation and foun- } \\
\text { dation erection, construction of basement and supporting structures } \\
\text { of the underground part of the building, occupational safety and } \\
\text { health, dispatching control }\end{array}$ \\
\hline Aboveground stage & $\begin{array}{l}\text { Construction documentation, construction and installation works, in- } \\
\text { stallation of communications, installation of engineering equipment, } \\
\text { industrial safety and labour protection, dispatching control }\end{array}$ \\
\hline Finishing stage & $\begin{array}{l}\text { Construction documentation, public premises finishing, apartment } \\
\text { finishing, facade finishing, territory improvement, industrial safety } \\
\text { and labour protection, dispatching control }\end{array}$ \\
\hline
\end{tabular}


From Table 2 it is visible that in the maintenance of a virtual building site there are universal and special items of the opening menu. Universal points are present at all stages (construction documentation, industrial safety and labour protection, dispatching control), only their content changes. Special items are specific to a particular stage. The content of the virtual construction site is based on the national code of practice for construction management [22].

\subsection{Criteria of efficiency for the introduction of a virtual building site in the educational process}

Criteria and indicators are interfaced with didactic functions of a virtual building site:

1. Interactive, allowing to simulate the process of construction with different degrees of detail, to increase students' interest in the profession, ensuring the safety of the educational process (virtual simulations are safer than visiting a real construction site);

2. Integrative, allowing to organise a feedback between subjects of educational process, promoting an establishment of interdisciplinary communications, providing involvement of the future builders in design and construction activity;

3. Competence, which allows to develop professional skills of the 21st century and digital literacy, contributes to the formation of professional individuality of students, ensures participation in the development of engineering products;

4. Methodical, allowing to personalise the educational process, promoting the transfer of emphasis from classroom to self-education, providing the visualisation of the technological process;

5. Control, allowing to organise monitoring of the development of knowledge, skills and abilities of students, contributing to the formation of a portfolio of students for the creation of engineering products, ensuring the objectivity of the assessment of learning outcomes.

Table 3 presents the interrelation of didactic functions of the virtual construction site with the criteria and indicators of the effectiveness of implementation in the educational process. 
Table 3. Didactic functions of the virtual construction site, Criteria and indicators of effectiveness of implementation in the educational process

\begin{tabular}{|c|c|c|c|c|}
\hline \multirow{2}{*}{ Functions } & \multirow{2}{*}{ Criteria } & \multicolumn{3}{|c|}{ Metrics } \\
\hline & & Knowledge & Skills & Skills \\
\hline Interactive & Metaparticle & $\begin{array}{l}\text { Know international } \\
\text { standard forms of } \\
\text { contracts for invest- } \\
\text { ment and construc- } \\
\text { tion activities }\end{array}$ & $\begin{array}{l}\text { Are able to apply in- } \\
\text { ternational and indus- } \\
\text { try standards of occu- } \\
\text { pational safety }\end{array}$ & $\begin{array}{l}\text { Own BIM (Building Infor- } \\
\text { mation Modelling) and } \\
\text { Smart technologies in con- } \\
\text { struction }\end{array}$ \\
\hline Integrative & Activity & $\begin{array}{l}\text { Know the national } \\
\text { code of conduct for } \\
\text { construction }\end{array}$ & $\begin{array}{l}\text { Are able to organise } \\
\text { electronic document } \\
\text { flow }\end{array}$ & $\begin{array}{l}\text { Own construction applica- } \\
\text { tions }\end{array}$ \\
\hline $\begin{array}{l}\text { Competency- } \\
\text { based }\end{array}$ & Digital & $\begin{array}{l}\text { Know the content of } \\
\text { the concept of "con- } \\
\text { struction site of the } \\
\text { future" }\end{array}$ & $\begin{array}{l}\text { Know how to search, } \\
\text { store, process, ana- } \\
\text { lyse information from } \\
\text { different sources and } \\
\text { databases }\end{array}$ & $\begin{array}{l}\text { Possess methods of present- } \\
\text { ing information in the re- } \\
\text { quired format using infor- } \\
\text { mation, computer and net- } \\
\text { work technologies }\end{array}$ \\
\hline Methodical & Relevant & $\begin{array}{l}\text { Know the values of } \\
\text { the professional com- } \\
\text { munity and the meth- } \\
\text { ods of self-education }\end{array}$ & $\begin{array}{l}\text { Know how to use } \\
\text { self-organisation ap- } \\
\text { plications for them- } \\
\text { selves and their time }\end{array}$ & Have teamwork skills \\
\hline Test & Complex & $\begin{array}{l}\text { Know the methods of } \\
\text { self-control in learn- } \\
\text { ing }\end{array}$ & $\begin{array}{l}\text { Can form-electronic } \\
\text { portfolio }\end{array}$ & $\begin{array}{l}\text { Know how to self-assess } \\
\text { and diagnose professional } \\
\text { skills }\end{array}$ \\
\hline
\end{tabular}

Table 3 shows that the criteria and indicators provide an indication of the level of awareness of digital opportunities in personal and professional life.

\subsection{Principles of selection and structuring of virtual construction site content}

The effectiveness of the virtual construction site implementation in the educational process increases with the determination of the principles of selection and structuring of its content. The effectiveness of the content is increased if the principles of selection and structuring are interlinked with the didactic functions of the virtual construction site (Table 4). 
Table 4. ctic functions of the virtual construction site, Principles of content selection and structuring

\begin{tabular}{|c|l|l|}
\hline \multicolumn{1}{|c|}{ Functions } & \multicolumn{1}{|c|}{ Selection principles } & \multicolumn{1}{|c|}{ Structuring principles } \\
\hline Interactive & $\begin{array}{l}\text { Rationality, including the introduction of dig- } \\
\text { ital representation of the construction industry } \\
\text { into the educational process } \\
\text { and digital technologies in the field of con- } \\
\text { struction planning and management }\end{array}$ & $\begin{array}{l}\text { Simulation to build interactive virtual } \\
\text { reality and develop skills in virtual pro- } \\
\text { ject development and management }\end{array}$ \\
\hline Integrative & $\begin{array}{l}\text { Integration that ensures the system integrity } \\
\text { of content (multimedia, text and graphic in- } \\
\text { formation, video, interactive presentations, } \\
\text { three-dimensional models) }\end{array}$ & $\begin{array}{l}\text { Unification, which ensures the intercon- } \\
\text { nection of digital, interactive, sensory } \\
\text { technologies for building a virtual, aug- } \\
\text { mented, mixed reality }\end{array}$ \\
\hline Competency-based & $\begin{array}{l}\text { SMART, providing for the development of } \\
\text { 21st century skills and digital literacy }\end{array}$ & $\begin{array}{l}\text { Immersion, including the use of infor- } \\
\text { mation modelling (BIM) }\end{array}$ \\
\hline Methodical & $\begin{array}{l}\text { Modularity, providing for autonomy of all } \\
\text { menu items and selection of educational ma- } \\
\text { terial factoring in the achievements of science } \\
\text { and technology }\end{array}$ & $\begin{array}{l}\text { subjectivity, which ensures personalisa- } \\
\text { tion of the educational process, non-lin- } \\
\text { ear structuring of content }\end{array}$ \\
\hline Test & $\begin{array}{l}\text { Multi-level, ongoing, thematic and final mon- } \\
\text { itoring and self-monitoring }\end{array}$ & $\begin{array}{l}\text { Efficiency, which allows to evaluate the } \\
\text { results of knowledge, skills and abilities } \\
\text { at any stage of the learning process }\end{array}$ \\
\hline
\end{tabular}

Table 4 shows that the principles of selection and structuring of content ensure its validity and updating.

\subsection{Experimental work to test the efficiency of the virtual construction site of a multi-storey residential building}

The experimental work was carried out in three stages (stating, forming, control). At the stating stage with the help of online survey the attitude of teachers and students to digital resources was found out, the criteria of efficiency of implementation of virtual construction site in the educational process were determined. The online survey was conducted in march 2018 and showed what the majority of teachers and students feel: digital literacy includes the ability to safely and effectively mine information from different resources (98 and 99\%), application of digital technologies in everyday and professional life (99 and 99\% ); to have digital technologies necessary for project management on the basis of modern software (95 and $98 \%$ ); successful adaptation to the labor market requirements (91 and 97\%); increasing personal competitiveness (94 and 97\%); visualisation of data needed.

However, the survey showed that students use digital resources more often (97\%) than teachers $(38 \%)$. The majority of students are not satisfied with the state of the university's digital resources (72\%). The majority of teachers in practice use digital resources as needed $(54 \%)$ and are dissatisfied with the state of the university's digital resources $(39 \%)$ (Table 5). 
Table 5. Results of an online survey of teachers $(\mathrm{T})$ and students $(\mathrm{S})$ on attitudes digital resources for pedagogical management of the educational process at stating the stage of experimental work $(\%)$

\begin{tabular}{|c|c|c|c|}
\hline Content of the question & Options for answers & $\mathbf{T}$ & $\mathbf{S}$ \\
\hline \multirow{3}{*}{$\begin{array}{l}\text { 1. Do you use digital resources } \\
\text { often? }\end{array}$} & 1.1 Often & 38 & 97 \\
\hline & 1.2. As needed & 54 & 2 \\
\hline & 1.3 Rarely. & 8 & 1 \\
\hline \multirow{3}{*}{$\begin{array}{l}\text { 2. Are you satisfied with the } \\
\text { state of the university's digital } \\
\text { resources? }\end{array}$} & 2.1 Yes. & 27 & 14 \\
\hline & 2.2. No. & 39 & 72 \\
\hline & 2.3. I'm having trouble answering & 34 & 14 \\
\hline \multirow{3}{*}{$\begin{array}{l}\text { 3. What kind of species digital } \\
\text { resources Do you prefer it? }\end{array}$} & 3.1 Interactive board & 68 & 92 \\
\hline & 3.2 Multimedia textbooks & 76 & 86 \\
\hline & 3.3 Virtual complexes & 81 & 93 \\
\hline \multirow{3}{*}{$\begin{array}{l}\text { 4. Why should virtual reality } \\
\text { technologies be adapted to the } \\
\text { learning process? }\end{array}$} & 4.1 To form a vision of the future construction site & 82 & 97 \\
\hline & 4.2 To develop the professional skills of the 21 st century & 91 & 96 \\
\hline & 4.3 To improve the effectiveness of training & 93 & 82 \\
\hline \multirow{3}{*}{$\begin{array}{l}\text { 5. Why possess digital technol- } \\
\text { ogy for a future engineer? }\end{array}$} & 5.1 For project management based on modern software & 95 & 98 \\
\hline & 5.2 For successful adaptation to labour market requirements & 91 & 97 \\
\hline & 5.3 To increase personal competitiveness & 94 & 97 \\
\hline \multirow{3}{*}{$\begin{array}{l}\text { 6. What do you mean by digital } \\
\text { literacy? }\end{array}$} & $\begin{array}{l}\text { 6.1 Ability to use information from different resources safely } \\
\text { and efficiently }\end{array}$ & 98 & 99 \\
\hline & $\begin{array}{l}\text { 6.2 Ability to effectively apply digital technologies in every- } \\
\text { day and professional life }\end{array}$ & 99 & 99 \\
\hline & $\begin{array}{l}\text { 6.3 Ability to effectively use and create content through digi- } \\
\text { tal technology }\end{array}$ & 56 & 71 \\
\hline \multirow{3}{*}{$\begin{array}{l}\text { 7. Why do you need to visual- } \\
\text { ise the data on the organisation } \\
\text { and management of construc- } \\
\text { tion in the training process? }\end{array}$} & $\begin{array}{l}\text { 7.1 To increase knowledge of innovative methods of organi- } \\
\text { sation and management in construction }\end{array}$ & 91 & 96 \\
\hline & 7.2 To simulate professional activities & 86 & 94 \\
\hline & $\begin{array}{l}\text { 7.3 To provide an opportunity to observe the construction } \\
\text { process step by step }\end{array}$ & 81 & 87 \\
\hline \multirow{3}{*}{$\begin{array}{l}\text { 8. What functions does the vir- } \\
\text { tual construction site perform? }\end{array}$} & 8.1 simulates the construction process & 93 & 98 \\
\hline & 8.2 Increases interest in the learning process & 91 & 93 \\
\hline & 8.3 Ensures safe learning & 62 & 76 \\
\hline \multirow{3}{*}{$\begin{array}{l}\text { 9. What should the virtual } \\
\text { training site include? }\end{array}$} & 9.1 Interactive 3D model of the object & 92 & 97 \\
\hline & 9.2 Animation of construction processes, video & 89 & 94 \\
\hline & $\begin{array}{l}\text { 9.3 Training animation film with additional text, graphics, in- } \\
\text { teractive presentations }\end{array}$ & 78 & 93 \\
\hline \multirow{3}{*}{$\begin{array}{l}10 \text {. What is the practical signif- } \\
\text { icance of a virtual construction } \\
\text { site? }\end{array}$} & 10.1 Establishes interdisciplinary links & 76 & 85 \\
\hline & 10.2 Allows organising design and construction activities & 81 & 83 \\
\hline & 10.3 Helps to personalise the learning process & 69 & 91 \\
\hline
\end{tabular}

Table 5 shows that teachers and students have a stable positive attitude towards digital resources of pedagogical management. Five online focus groups were created from teachers and students to discuss the results of the survey in the forum mode. Each focus group included 19 people: 10 teachers and 9 students. Students were appointed as focus group moderators. Focus groups found out the criteria of efficiency of virtual construction site implementation in the educational process: metaproject, activity, digital, relevant, complex. Criteria allow to identify the achieved results with didactic functions of 
the virtual construction site, provide completeness of information about the effectiveness of implementation in the educational process, allow to determine the gradient of growth of professional skills of the 21 st century and digital literacy, necessary for successful adaptation to the requirements of the labour market and increase of personal competitiveness.

At the formative stage, the educational material (content) was selected and structured, and a virtual construction site for a multi-storey residential building was created. The virtual construction site made it possible to organise individual and group work of students to ensure industrial and occupational safety during the construction of a multistorey residential building (Fig. 3).

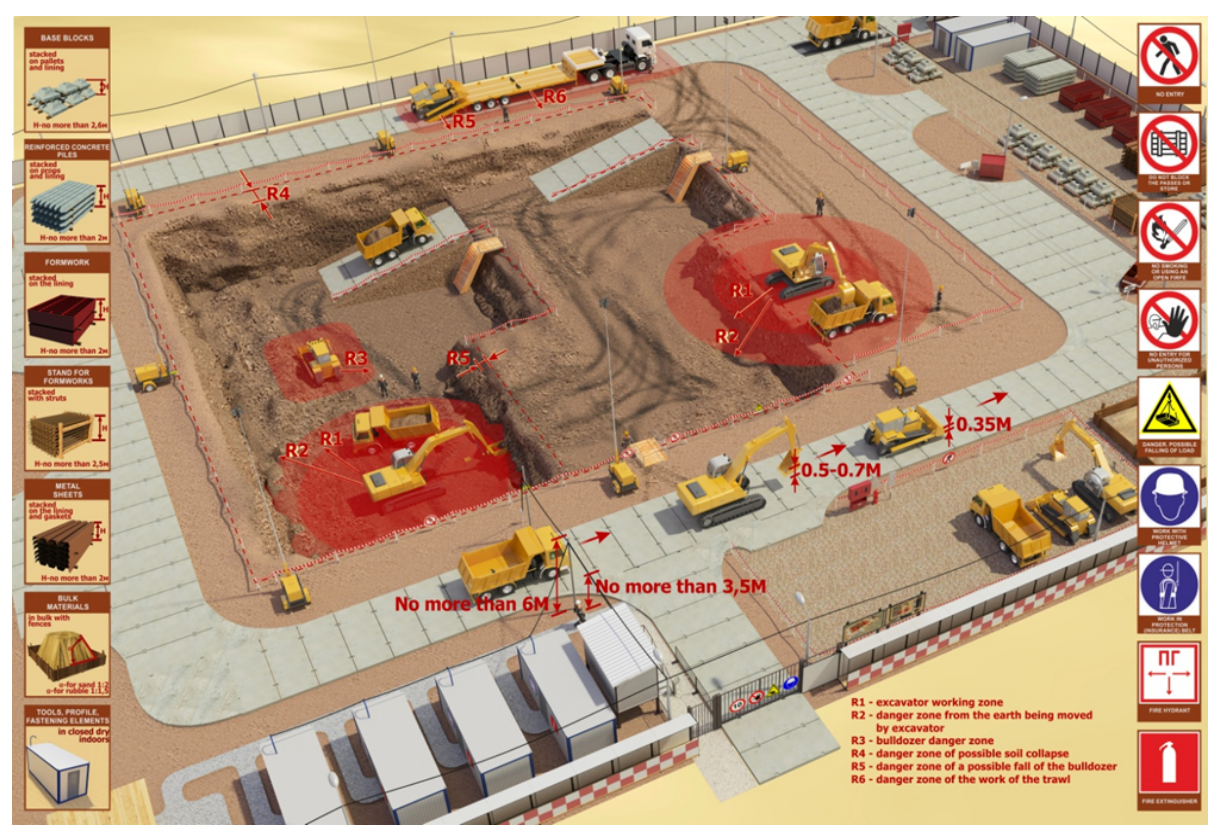

Fig. 3. Three-dimensional poster for safe earthworks

Fig. 3 shows that the content of the virtual construction site allows to integrate professionally significant knowledge, skills and abilities up to the level of professional competence in ensuring industrial safety and labour protection. Students were asked to work individually or to organise groups of 2-3 people.

The participants were given a roadmap of training assignments on industrial and occupational safety at each stage of construction. Each assignment was rated at 5 points. The total number of tasks is 16 . A total of 80 points can be scored on the road map. The content of the roadmap is aimed at: consolidating the knowledge of norms and standards aimed at ensuring industrial and occupational safety; understanding the consequences of violations of safety requirements to production and technological processes; understanding the meaning of industrial and occupational safety, which allows identifying hazards. 
Based on the results of the roadmap implementation, the participants prepared interactive reports and projects for the creation of a virtual consulting centre "Industrial and Occupational Health and Safety in Construction", which will allow to conduct consultations of employees in real time (Table 6).

Table 6. Roadmap of industrial and occupational health and safety training tasks performed at the virtual construction site of a multi-storey residential building

\begin{tabular}{|c|c|c|c|c|c|}
\hline \multirow[b]{2}{*}{$\begin{array}{l}\text { Stages of con- } \\
\text { struction }\end{array}$} & \multicolumn{4}{|c|}{ Ensuring industrial and occupational safety and health } & \multirow[b]{2}{*}{$\begin{array}{c}\text { Date and } \\
\text { number of } \\
\text { points }\end{array}$} \\
\hline & $\begin{array}{c}\text { Safety Technol- } \\
\text { ogy }\end{array}$ & Fire safety & \begin{tabular}{|c|} 
Sanitary and hy- \\
gienic working \\
conditions
\end{tabular} & $\begin{array}{l}\text { Supervision } \\
\text { and control }\end{array}$ & \\
\hline Preparatory & $\begin{array}{l}\text { Prepare a set of or- } \\
\text { ganisational and } \\
\text { technical measures } \\
\text { and means to pre- } \\
\text { vent fatalities and } \\
\text { injuries }\end{array}$ & $\begin{array}{l}\text { Identify and substan- } \\
\text { tiate ten risk factors } \\
\text { for fire safety of em- } \\
\text { ployees }\end{array}$ & $\begin{array}{l}\text { Create an elec- } \\
\text { tronic poster on } \\
\text { occupational dis- } \\
\text { ease prevention }\end{array}$ & $\begin{array}{l}\text { Develop a } \\
\text { roadmap for } \\
\text { prevention of } \\
\text { industrial acci- } \\
\text { dents }\end{array}$ & \\
\hline Underground & $\begin{array}{l}\text { Create a set of } \\
\text { electronic posters } \\
\text { on industrial } \\
\text { safety and labour } \\
\text { protection in the } \\
\text { course of excava- } \\
\text { tion works (1 } \\
\text { piece); construc- } \\
\text { tion of the base } \\
\text { and foundation (1 } \\
\text { piece); construc- } \\
\text { tion of the base- } \\
\text { ment and support- } \\
\text { ing structures } \\
(1 \text { unit); trenching } \\
\text { for communica- } \\
\text { tions (1 unit) }\end{array}$ & $\begin{array}{l}\text { Prepare a set of } \\
\text { measures to reduce } \\
\text { the risk of fire in the } \\
\text { implementation of } \\
\text { working processes }\end{array}$ & $\begin{array}{l}\text { Identify and sub- } \\
\text { stantiate ten risk } \\
\text { factors for sani- } \\
\text { tary and hygienic } \\
\text { working condi- } \\
\text { tions }\end{array}$ & $\begin{array}{l}\text { Give a charac- } \\
\text { terisation of ten } \\
\text { smart technolo- } \\
\text { gies controls. } \\
\text { Compliance } \\
\text { with industrial } \\
\text { and occupa- } \\
\text { tional safety } \\
\text { standards in the } \\
\text { construction in- } \\
\text { dustry }\end{array}$ & \\
\hline Aboveground & $\begin{array}{l}\text { Identify and jus- } \\
\text { tify safety risk fac- } \\
\text { tors construction } \\
\text { and installation } \\
\text { works (ten fac- } \\
\text { tors), installation } \\
\text { of communica- } \\
\text { tions (ten factors), } \\
\text { installation of en- } \\
\text { gineering equip- } \\
\text { ment (ten factors) } \\
\end{array}$ & $\begin{array}{l}\text { Create a set of elec- } \\
\text { tronic posters for fire } \\
\text { safety construction } \\
\text { and installation } \\
\text { works ( } 1 \text { piece), in- } \\
\text { stallation of commu- } \\
\text { nications } \\
(1 \text { piece }) \text {, installation } \\
\text { of engineering } \\
\text { equipment ( } 1 \text { piece })\end{array}$ & $\begin{array}{l}\text { To develop a } \\
\text { roadmap for as- } \\
\text { sessment of sani- } \\
\text { tary and hygienic } \\
\text { working condi- } \\
\text { tions and organi- } \\
\text { sation of neces- } \\
\text { sary measures } \\
\text { for their im- } \\
\text { provement }\end{array}$ & $\begin{array}{l}\text { Prepare a set of } \\
\text { measures to su- } \\
\text { pervise and } \\
\text { control compli- } \\
\text { ance with in- } \\
\text { dustrial safety } \\
\text { and labour pro- } \\
\text { tection stand- } \\
\text { ards }\end{array}$ & \\
\hline Finishing & $\begin{array}{l}\text { Develop an elec- } \\
\text { tronic instruction } \\
\text { on occupational } \\
\text { safety during fin- } \\
\text { ishing works }\end{array}$ & $\begin{array}{l}\text { Give one smart char- } \\
\text { acteristic. Fire safety } \\
\text { technology }\end{array}$ & $\begin{array}{l}\text { Prepare a set of } \\
\text { measures to pro- } \\
\text { vide employees } \\
\text { working in haz- } \\
\text { ardous condi- } \\
\text { tions with pro- } \\
\text { tective equip- } \\
\text { ment }\end{array}$ & $\begin{array}{l}\text { Create an elec- } \\
\text { tronic poster on } \\
\text { legal responsi- } \\
\text { bility for viola- } \\
\text { tions of indus- } \\
\text { trial safety and } \\
\text { labour protec- } \\
\text { tion standards }\end{array}$ & \\
\hline
\end{tabular}


From Table 6 it is visible that the road map allows opening pedagogical potential of a virtual building site. First, modern technologies are integrated with methods and means of training for development of professional skills of the 21 st century and digital literacy. Second, the educational process is detailed, providing a steady orientation of teachers and students on achieving the set results of training.

At a control stage of experimental work levels of mastering of a training material on the organisation and management of the construction of a multi-storey apartment house are revealed. Students were asked to answer the questions and complete the assignments, which were evaluated using the 5-point system (Table 7).

Table 7. Mastering by students of the educational material on ascertaining (ascertaining) and control stages of experimental work (average score)

\begin{tabular}{|c|c|c|}
\hline \multirow{2}{*}{ Criteria and Indicators } & \multicolumn{2}{|c|}{ Stages } \\
\hline & Ascertaining & Control \\
\hline \multicolumn{3}{|l|}{ Meta-subject criterion (M) } \\
\hline $\begin{array}{l}\text { 1. Know international standard forms of contracts for investment and con- } \\
\text { struction activities }\end{array}$ & 3.5 & 4.6 \\
\hline 2. Can apply international and industry safety standards & 3.6 & 4.3 \\
\hline 3. Possess BIM and Smart technologies in construction & 2.8 & 4.8 \\
\hline \multicolumn{3}{|l|}{ Activity Criterion (A) } \\
\hline 4. know the national code of conduct for construction & 3 & 4.8 \\
\hline 5. are able to organise electronic document flow & 2.8 & 4.5 \\
\hline 6.Own the construction applications & 2.9 & 4.9 \\
\hline \multicolumn{3}{|l|}{ Digital Criterion (D) } \\
\hline 7. know the content of the concept of "construction site of the future" & 2.9 & 5 \\
\hline 8. Can search, store and process information from different databases & 3.1 & 4.9 \\
\hline 9) Possess the methods of presenting information using digital technologies & 3.7 & 4.8 \\
\hline \multicolumn{3}{|l|}{ Relevant criterion $(R)$} \\
\hline $\begin{array}{l}\text { 10. know the values of the professional community and methods of self-edu- } \\
\text { cation }\end{array}$ & 4.1 & 4.9 \\
\hline 11. are able to use self-organisation applications for themselves and their time & 2.7 & 4.8 \\
\hline 12. Have teamwork skills & 4.2 & 4.9 \\
\hline \multicolumn{3}{|l|}{\begin{tabular}{|c|} 
Complex Criterion (C) \\
\end{tabular}} \\
\hline 13. know the methods of self-control in learning & 4.3 & 4.8 \\
\hline 14. Can form an electronic portfolio & 4.5 & 4.9 \\
\hline $\begin{array}{l}\text { 15. possess the methods of self-assessment and diagnostics of professional } \\
\text { skills }\end{array}$ & 3.9 & 5 \\
\hline
\end{tabular}

Table 7 shows that the development of educational material with the help of the content of the virtual construction site creates a positive dynamic. In order to identify the levels of mastery of educational material at the stating and control stages, we determined the value $(\mathrm{Q})$ as the sum of values $(\mathrm{V})$ for each criterion: $\mathrm{Q}=\mathrm{VM}+\mathrm{VA}$ $+\mathrm{VD}+\mathrm{VR}+\mathrm{VC}$

The values for each criterion were calculated using a formula: $\mathrm{V}=\mathrm{qi} \mathrm{n} \Sigma /$, where qi is the average score obtained for the indicator, $n$ is the number of indicators of the criterion. 
Values (Q) from 0 to 8 are conditionally considered as a low level; from 9 to 17 - an average level; from 18 to 25 - a high level. The characteristics of the levels are as follows.

Low level. Students know the legal basis for organising and managing the construction of a multi-storey residential building, the distinctive features of the "construction site of the future", but have difficulty in reviewing the values of the construction community. Can ensure industrial and occupational safety, but without the use of digital technologies. Recognise the importance of digital literacy in personal and professional activities, but have very limited knowledge of building applications. Ready to work in a team, but not able to independently control personal and professional development.

Medium level. Students know the values of the construction community, the legal basis for the organisation and management of the construction of a multi-storey residential building, and the distinguishing features of the "construction site of the future". They can properly organise the construction process and ensure industrial safety and labour protection at each stage, but only partially using digital technologies. In addition, they recognise the importance of digital literacy in personal and professional life, but the construction applications are partially owned. They are also ready to work in a team, but not yet able to independently control personal and professional development.

High level. Students know the values of the construction community, the legal basis for the organisation and management of the construction of a multi-storey residential building, and the distinguishing features of the "construction site of the future". They can properly organise the construction process and ensure industrial safety and labour protection at each stage, but only partially using digital technologies. In addition, they recognise the importance of digital literacy in personal and professional life, but the construction applications are partially owned. They are also ready to work in a team and independently organise personal and professional development and increase competitiveness in the labour market.

The problem of introducing digital resources into the pedagogical management of the educational process of the construction university attracts great attention of scientists. There are several scientific approaches to solving this problem.

The first approach is contextual. Context - a complete excerpt of speech (text), the general meaning of which allows clarifying the meaning of the words and sentences included in it. More broadly, context is the environment in which an object exists [23]. As part of this approach, the subject matter of the study is the pedagogical management tools that provide a new vision of the construction site. Pedagogical management is characterised by real-time context awareness embedded in building applications and universal information and communication technology applications. Pedagogical management tools may include:

- Online resources included in the training process [5] to enhance knowledge of innovative site management practices [3,24]

- Interactive learning methods [4] to develop skills to process and analyse information from a variety of sources and databases and to present it in the required format using information, computer and networking technologies [17] 
- Multimedia training courses and e-textbooks, the implementation of which contributes to the development of skills to collect and systematise information and raw data, computer modelling [7]

- -A unified educational environment that is organised for the development of skills in navigation in the public network, wireless local area network, satellite communication system of global positioning [15]

The main functions of the abovementioned pedagogical management tools are to 1) "Learning to live", which implies a new understanding of digital opportunities [16] and 2) Developing an information-adapted student [25].

The second approach is intellectual. The subject of the research is the tools of pedagogical management, which provide the development of sustainable skills in the design and implementation of intelligent building sites and systems of delivery of necessary information at the right time and place, application of virtual methods of human resources management, automated classification of documents, and visualisation of data on building management [24]. The following tools are offered as part of an intellectual approach:

- Improving the electronic learning environment to develop self-organisation and selfeducation skills through the creation of web pages by teachers and students and the organisation of video conferences [26]

- The use of cloud services and the expansion of access to a variety of educational products to develop the ability of students to search, store, analyse and integrate different types of information obtained from web services [9]

- Introduction of BIM-technology to build students' ability to manage projects based on universal and specialised software [27], including the use of four-dimensional (4D) and five-dimensional (5D) models [28];

- The use of virtual reality technologies to build 21 st century skills $[29,30]$, by reflecting real-world construction conditions [31], and hosted on desktops, mobile devices [8], and in 3D games [32]

The main functions of the abovementioned pedagogical management tools are to:

1. Develop the ability to respond quickly to changes in the environment [33]; adapt to changing conditions [34]; refine self-development and self-control [10]

2. Personalise learning and inclusion in the process of building information modeling [35] and organise personal and professional development [36]

3. Improve the competitiveness of future engineers [24], develop the ability to implement projects in an integrated manner, and develop 21st century skills [1]

The conclusions drawn by these authors form the basis of the study. However, the active introduction of digital resources into pedagogical management of the learning process requires the definition of a paradigm. 


\section{Conclusion}

Practical recommendations for the effective implementation of digital resources in educational management are as follows. The importance of digital resources in pedagogical management increases with the digital literacy of future professionals. The actualisation of the involvement of digital resources in pedagogical management increases with the adaptation of virtual reality technologies to the learning objectives. Effective pedagogical management is enhanced when traditions and innovations in learning are linked. The effectiveness of pedagogical management based on the digital paradigm increases with the development of professional skills of the 21 st century. Optimisation of pedagogical management based on the digital paradigm is enhanced by the development of open educational resources based on digital content.

The obtained results allow us to outline the prospects for further research on this problem, which is related to the organisation of the virtual learning environment, as well as the identification of risks of the introduction of digital educational resources. This study $\backslash$ findings can be useful for teachers of building universities and employees of the centres of advanced training of engineers-constructors.

\section{$5 \quad$ References}

[1] Kivunja, C. (2014). Teaching students to learn and to work well with 21st century skills: Unpacking the career and life skills domain of the new learning paradigm. International Journal of Higher Education, 4(1): 1-11. https://doi.org/10.5430/ijhe.v4n1p1

[2] Nazartseva, E. A., Morya, L. A., Zubanova, S. G. (2019). Teaching foreign students the vocation-related language. Amazonia Investiga, 8(22): 338-343.

[3] Kumar, V., Nanda, P. (2019). Social media in higher education: A framework for continuous engagement. International Journal of Information and Communication Technology Education, 15(1): 109-120. https://doi.org/10.4018/ijicte.2019010107

[4] Brecka, P., Valentova, M. (2017). Model of the students' key competences development through interactive whiteboard in the subject of technology. Informatics in Education, 16(1): 25-38. https://doi.org/10.15388/infedu.2017.02

[5] Kalelioglu, F. (2017). Using Facebook as a learning management system: Experiences of pre-service teachers. Informatics in Education, 16(1): 83-101. https://doi.org/10.15388/inf edu.2017.05

[6] Johannessen, J.-A., Johannessen, J.-A. (2018). Knowledge management and organisational learning. In Knowledge Management as a Strategic Asset (pp. 95-111). Emerald Publishing Limited. https://doi.org/10.1108/978-1-78769-659-420181005

[7] Brilingaite, A., Bukauskas, L., Juskeviciene, A. (2018). Competency assessment in problembased learning projects of information technologies students. Informatics in Education, 17(1): 21-44. https://doi.org/10.15388/infedu.2018.02

[8] Aldalalah, O. M., Ababneh, Z., Bawaneh, A., Alzubi, W. (2019). Effect of augmented reality and simulation on the achievement of mathematics and visual thinking among students. International Journal of Emerging Technologies in Learning, 14(18): 164-185. https://doi.org/10.3991/ijet.v14i18.10748 
[9] Abdelhag, M. E. (2015). SOA for dynamically integrated virtual learning environment systems with cloud based services. International Journal of Computer Applications Technology and Research, 4(2): 124-127.

[10] Meins-Becker, A., Kelm, A., Laußat, L., \& Helmus, M. (2015). New drafts for the integration of modern technologies and methods in education and training. In ISEC 2015 - 8th International Structural Engineering and Construction Conference: Implementing Innovative Ideas in Structural Engineering and Project Management (pp. 1197-1201). ISEC Press. https://doi.org/10.14455/isec.res.2015.202

[11] Heider, K., Laverick, D., Bennett, B. (2009). Digital textbooks : The next paradigm shift in higher education? Association for the Advancement of Computing in Education Journal, 17(2): 103-112.

[12] Abderrahim, E. M., Mohamed, E., Azeddine, N. (2013). An evaluation model of digital educational resources. International Journal of Emerging Technologies in Learning, 8(2): 2935.

[13] Deloitte (2019). What is Digital Economy? [Online]. Available: https://www2.deloitte. $\mathrm{com} / \mathrm{mt} / \mathrm{en} / \mathrm{pages} / \mathrm{technology} /$ articles/mt-what-is-digital-economy.html [Accessed October 19, 2019].

[14] Digital Research LLC (2017). [Online]. Available: http://digitalresearch.ru/index.html [Accessed October 19, 2019].

[15] Mihailidis, P. (2018). Civic media literacies: re-Imagining engagement for civic intentionality. Learning, Media and Technology, 43(2): 152-164. https://doi.org/10.1080/ $\underline{17439884.2018 .1428623}$

[16] McDougall, J., Readman, M., Wilkinson, P. (2018). The uses of (digital) literacy. Learning, Media and Technology, 43(3): 263-279. https://doi.org/10.1080/17439884.2018 .1462206

[17] Takala, T. M., Malmi, L., Pugliese, R., Takala, T. (2016). Empowering students to create better virtual reality applications: A longitudinal study of a VR capstone course. Informatics in Education, 15(2): 287-317. https://doi.org/10.15388/infedu.2016.15

[18] Hengky, S. H. (2013). Fundamentals of human resource management. Journal of Human Resources Management and Labor Studies, 1(2): 39-40.

[19] UNESCO (2015). UNESCO Science Report, Towards 2030. [Online]. Available: https://en.unesco.org/unesco_science_report [Accessed December 19, 2019].

[20] VirtualExS (2019). [Online]. Available: https://virtualexs.ru [Accessed December 19, 2019].

[21] Autodesk (2019). [Online]. Available: https://www.autodesk.ru/[Accessed October 19, 2019].

[22] Ministry of Development of the Russian Federation (2011). Organization of construction. [Online]. Available: http://docs.cntd.ru/document/1200084098[Accessed December 19, 2019].

[23] Dey, A. K. (2001). Understanding and using context. Personal and Ubiquitous Computing, 5(1): 4-7.

[24] Edirisinghe, R. (2019). Digital skin of the construction site. Engineering, Construction and Architectural Management, 26(2): 184-223. https://doi.org/10.1108/ecam-04-2017-0066

[25] Im, D. U., Lee, J. O. (2013). Mission-type education programs with smart device facilitating LBS. International Journal of Multimedia and Ubiquitous Engineering, 8(2): 81-88

[26] Wiessner, C. A., Hatcher, T., Chapman, D., Storberg-Walker, J. (2008). Creating new learning at professional conferences: An innovative approach to conference learning, knowledge construction and programme evaluation. Human Resource Development International, 11(4): 367-383. https://doi.org/10.1080/13678860802261488 
[27] Gledson, B. J., Dawson, S. (2017). Use of simulation through BIM-enabled virtual projects to enhance learning and soft employability skills in architectural technology education. In Building Information Modelling, Building Performance, Design and Smart Construction (pp. 79-92). Springer, Cham. https://doi.org/10.1007/978-3-319-50346-2_6

[28] Sampaio, A. Z. (2018, July). Introduction of BIM methodology in education: Concept and application. In 4th International Conference on Higher Education Advances (HEAD'18) (pp. 19-27). Editorial Universitat Politècnica de València. https://doi.org/10.4995/head18. $\underline{2018.7443}$

[29] Park, C. S., Le, Q. T., Pedro, A., Lim, C. R. (2016). Interactive building anatomy modeling for experiential building construction education. Journal of Professional Issues in Engineering Education and Practice, 142(3): 04015019. https://doi.org/10.1061/(asce)ei.19 $\underline{43-5541.0000268}$

[30] Peng, W., Peng, W., Jun, W., Hung-Lin, Ch., Xiangyu, W. (2018). A critical review of the use of virtual reality in construction engineering education and training. International Journal of Environmental Research and Public Health, 15(6): 1204.

[31] Virtual Construction Site - Gaia Studio (2019). [Online]. Available: https://studio.gaiatech.com/product/virtual-construction-site/ [Accessed October 19, 2019].

[32] Goedert, J. D., Rokooei, S. (2016). Project-based construction education with simulations in a gaming environment. International Journal of Construction Education and Research, 12: 208-223. https://doi.org/10.1080/15578771.2015.1121936

[33] Zhang, Y., Lu, L.-W. (2008). Introducing smart structures technology into civil engineering curriculum: Education development at Lehigh University. Journal of Professional Issues in Engineering Education and Practice, 134(1): 41-48. https://doi.org/ $10.1061 /($ asce) $1052-3928(2008) 134: 1(41)$

[34] Suwal, S., Singh, V. (2018). Assessing students' sentiments towards the use of a Building Information Modelling (BIM) learning platform in a construction project management course. European Journal of Engineering Education, 43(4): 492-506. https://doi.org/10.10 $\underline{80 / 03043797.2017 .1287667}$

[35] Yi, T., Yun, S. (2018). BIM (Building Information Modeling) Education Program in KSA: A Case Study of BIM program at Prince Sultan University. In E3S Web of Conferences (Vol. 65, p. 04004). EDP Sciences. https://doi.org/10.1051/e3sconf/20186504004

[36] De Amicis, R., Riggio, M., Shahbaz Badr, A., Fick, J., Sanchez, C. A., Prather, E. A. (2019). Cross-reality environments in smart buildings to advance STEM cyberlearning. International Journal on Interactive Design and Manufacturing, 13(1): 331-348. https://doi. org/10.1007/s12008-019-00546-X

\section{$6 \quad$ Authors}

Pugacheva Natalya is Doctor of Education andProfessor at Department of Building Technology, Kazan State University of Architecture and Engineering, Kazan, Russia.

Kirillova Tatyana is $\mathrm{PhD}$ and Professor at Research Institute of the Federal Penitentiary Service of Russia, Moscow, Russia, Center of a research of problems of execution of criminal penalties and psychological ensuring professional activity of staff of penal correction system, Moscow, Russia.

Kirillova Olga is $\mathrm{PhD}$, and Professor at Department of philosophy, sociology and pedagogy, Chuvash State University named after Ulyanov, Cheboksary, Russia. 
Luchinina Anastasia is a candidate of Pedagogical Sciences andAssociate Professor atDepartment of Pedagogics, Vyatka State University, Kirov, Russia.

Korolyuk Irina is a teacher in College of State and Municipal Service, Izhevsk, Russia.

Lunev Aleksandr is PhD, Professor atDepartment of Engineering Production Technology, Kazan National Research Technical University named after Tupolev, Kazan, Russia.

Article submitted 2020-04-23. Resubmitted 2020-05-23. Final acceptance 2020-05-25. Final version published as submitted by the authors. 